Article received on $3^{\text {rd }}$ Jun 2014

Article accepted on $14^{\text {th }}$ Jun 2014

UDC: $78.091 .4(497.11)$

78.071.1:929 Мокрањац Стојановић C.

\author{
Jelena Arnautovic** \\ University of Priština \\ Faculty of Arts
}

\title{
VARIOUS 'FACES' OF STEVAN MOKRANJAC AT THE MOKRANJČEVI DANI FESTIVAL IN THE $21^{\text {ST }}$ CENTURY $^{1}$
}

\begin{abstract}
The discourses on Stevan Stojanović Mokranjac, as one of the most significant composers in the history of Serbian music, reflect not only our attitude towards the composer, but also toward ourselves and the community to which we belong. The objects of analysis in this item are the discourses on Mokranjac in the $21^{\text {st }}$ century, particularly at the festival Mokranjčevi dani in Negotin. A deconstruction of the narratives which are an integral part of the festival, primarily keynote addresses, as well as articles about the festival in printed media and on websites, shows that Mokranjac is interpreted as an important symbol of Serbian identity. Since Mokranjac is mythologized as an original artist, a genius who sang 'from the very soul of the Serbian people', the glorification of Mokranjac, traditional folklore, and Eastern Orthodoxy grows into a large-scale glorification of the entire Serbian nation. In some other narratives, Mokranjac is understood as a cosmopolitan, a manager, and a potential brand that may help us make a better showing on the international stage and be used for building an identity based on 'European civic values'. These various 'faces' of Stevan Mokranjac reflect different ways in which music tradition, as a powerful means of identification, can be utilized, invented, selectively remembered, or in fact forgotten.
\end{abstract}

Key words: Stevan Mokranjac, Mokranjčevi dani, narratives, Serbian identity, tradition, symbol, mythologization

\footnotetext{
* Author contact information: jelena_arnautovic@yahoo.com

1 This paper is an abridgment of more comprehensive research that I am conducting for the purposes of my doctoral thesis, entitled Muzički festivali u Srbiji u prvoj deceniji 21. veka kao mesta interkulturnih dijaloga [Music Festivals in Serbia in the First Decade of the 21 ${ }^{\text {st }}$ Century as Places of Intercultural Dialogues] under the supervision of Dragana Jeremić Molnar, PhD, Associate Professor at the Department of Musicology of the Faculty of Music in Belgrade.
} 
The festival Mokranjčevi dani [The Days of Mokranjac] is dedicated to Stevan Stojanović Mokranjac and it has been held in Negotin, his hometown, every year since $1966 .{ }^{2}$ The core of the festival programme is made of Mokranjac's compositions, but also comprises the works by many other authors of a comparable stylistic orientation. For several decades, the festival has been a venue for performers and researchers of Mokranjac's oeuvre, as well as various composers and artists whose creative output resonates with Mokranjac's in one way or another. Over the course of the history of Mokranjčevi dani, views of Mokranjac have changed, and so I will try in this paper to determine in what way is Mokranjac talked about at the festival today, in the $21^{\text {st }}$ century. To that end, I have analysed the narratives which are an integral part of the festival Mokranjčevi dani (keynote addresses and speeches at the festival's opening and closing ceremonies and within the festival forum), ${ }^{3}$ and the narratives about Mokranjčevi dani in printed media and on websites. ${ }^{4}$

The festival Mokranjecevi dani in the first decade of the $21^{\text {st }}$ century is dominated by narratives which - by means of the Romantic ideal of an original artist, a genius - lead to a sort of mythologisation of Mokranjac. ${ }^{5} \mathrm{He}$ is spoken

\footnotetext{
2 The founder and main sponsor of Mokranjčevi dani is the Town Council of Negotin and the organizer is the Stevan Mokranjac Cultural Centre in Negotin. Today, the festival enjoys the status of a state-level event of national and international significance.

${ }^{3}$ A keynote address has been a regular feature at the opening ceremony at Mokranjčevi dani since 1969, and the speakers are selected distinguished individuals from Serbia's cultural life. Speeches at the festival opening and closing ceremonies are entrusted to the programming directors and organizers, but also to politicians and other important public figures.

${ }^{4}$ The sources used for the purposes of this research are the journal Mokranjac (published annually by the Stevan Mokranjac Cultural Centre in Negotin), selected reviews of the festival Mokranjčevi dani from various daily newspapers (Politika, Timok, Danas, Večernje novosti, Politika ekspres, Blic, Glas, etc.), as well as texts published on websites of the festival, the Cultural Centre and the Municipality of Negotin.

${ }^{5}$ Analysing scholarly discourses on Mokranjac, Tijana Popović-Mlađenović has concluded that the Romantic 'myth of un/originality' was the basic criterion for evaluating his oeuvre almost until the end of the $20^{\text {th }}$ century. His music, being based on folklore, was considered 'unoriginal'. Cf. Tijana Popović-Mlađenović, "Recepcija stvaralaštva St. St. Mokranjca u kontekstu savremene pisane reči o muzici" ["The Reception of St. St. Mokranjac's Oeuvre in the Context of Contemporary Writing on Music"], Mokranjac, 2011, 13, 2-20. Paradoxically, the same myth has been revitalized in contemporary non-scholarly narratives on Mokranjac, precisely for the purpose of glorifying his 'originality'. Vesna Mikić has written about contemporary positions and interpretations of Mokranjac in Serbian culture and education, tackling the questionability of narratives advanced at the festival Mokranjcevi dani. Cf. Vesna Mikić, “NNaš’ Mokranjac - tranzicijske kulturne prakse i delo Stevana Mokranjca" ["“Our' Mokranjac - Transitional Cultural Practices and the Oeuvre of Stevan Mokranjac"], Mokranjac, 2012, 14, 2-12.
} 
about as "nedokučivom geniju iz Negotina" ["the unfathomable genius from Negotin"] and "našem poslednjem autentičnom velikanu" ["our last genuine greatness"], whose creativity was motivated "iskonskim talentom koji je nosio u sebi" ["by the primordial talent that he carried in himself"]. ${ }^{6}$ The mythologisation of Mokranjac is most obvious in the festival keynote addresses. The very fact that this dated verbal form, atypical of contemporary festivals, has been favoured to this day suggests the need to lend Mokranjac the importance of a traditional, historically very significant, almost legendary, and mythological phenomenon. ${ }^{7}$ In the keynote addresses, he is portrayed as a miracle, a medium between humankind, the mundane, and something unfathomable and supernatural, a figure whose character and work must be treated with utmost reverence.

As an example, we can take the keynote address delivered in 2010 by the renowned frula player Bora Dugić, who approached Mokranjac's biography in a way that almost calls forth the descriptions of Christ's birth. "Nalazimo se na mestu gde je te, 1856. godine, trećeg dana Božića, svetlost sunca ugledao muškarčić ni po čemu različit od novorođene dece toga doba" ["We are standing at the place where in 1856, on the third day of Christmas, a little boy saw the light of day, a boy who was no different from any other newborn child at the time"]. However, he "svojim genijalnim talentom nesebično uzdigao srpski svetovni i muzički opus u neviđene visine" ["and his talent of a genius selflessly took Serbian secular and musical oeuvre to unimagined heights"] and reached a glory that "svrstala ga u klasike i besmrtnike" ["placed him among great masters and immortals"]. As soon as he had finished his education abroad, Mokranjac embarked on "veliku misiju uzdizanja narodnog stvaralaštva do nečutih i nepojmljivih visina" ["a great mission to exalt the folklore to heights unheard of and inconceivable"] because all of his choral works "odišu visinom, dubinom i širinom duha" ["exude spirituality in all its height, depth, and breadth"]. The myth becomes more convincing if one adds at least some ordinary and familiar features to it, and so this "istinski genije" ["veritable genius"] also had attributes of a joyful and witty man, "narodnog u duši, sa gradskim

6 Marija Adamov, "Dela Svetislava Božića" ["Works by Svetislav Božić"], Dnevnik, 15 September 2001; Milovan Nikolić, "Beseda" ["Keynote Address"], Baštinik, Godišnjak Istorijskog arhiva u Negotinu, 2006, 9, 144.

7 One of the few festivals in Serbia that still feature keynote addresses is Dragačevski sabor trubača [Trumpet Players Assembly in Dragačevo] in Guča. The character of the keynote addresses is similar to those at Mokranjčevi dani, except that the object of mythologization in Guča is - the trumpet. Given that both festivals have roots in traditional folklore celebrations, and that they were very similar in the initial stages of their development, one can assume that this firm connection with folklore was the main reason for introducing and retaining keynote addresses as a regular feature at both festivals. 
otmenim ruhom, ali i strogim, dostojanstvenim licem" ["in his heart a man of the people, wearing elegant urban attire, but also having a stern and dignified countenance"]. ${ }^{8}$

The mythologization of Mokranjac then spreads diffusely to cover the entire festival and the city hosting it. Thus, the press and keynote addresses describe Mokranjčevi dani as a "svetkovina muzike" ["festivity of music"] and "istinski praznik kulture i umetnosti" ["a genuine celebration of culture and art"], while Negotin is labelled "muzička metropola" ["musical metropolis"], "mesto hodočašća" ["a place of pilgrimage"], "hram kulture" ["a temple of culture"], "sveto mesto za srpsku kulturu" ["a sanctum of Serbian culture"]. 9 Similar references are used for Mokranje, the village where Mokranjac's family came from. Thus, for instance, one can read that, at the 2010 edition of the festival, the First Belgrade Choral Society "stiglo u Mokranje na poklonjenje ishodištu velikog maga srpske muzike" ["arrived in Mokranje to pay homage to the place of origin of the great master of Serbian music"]. ${ }^{10}$

While the narratives glorifying Mokranjac are somewhat understandable and justified, given the purpose of the festival, the problem arises when Mokranjac is interpreted as a symbol of Serbian identity and a means to fortify the sense of fellowship. For example, Milovan Nikolić, professor of literature, in his keynote address from 2005 emphasized that Mokranjac had paved the way for generations of musicians who would "na temeljima postojećeg graditi novo čuvajući identitet duše srpskog naroda" ["build on existing foundations, preserving the identity of the soul of the Serbian people"]. ${ }^{11}$ Similar was the drift of the speech by the theatre director Nebojša Bradić, who as the Minister of Culture opened Mokranjčevi dani in 2010. On the occasion, Bradić stressed that "naša privilegija u tome što za Mokranjca znamo otkako znamo za sebe same" ["we are privileged to have known about Mokranjac for as long as we can remember"]. For, one could say about poets that they speak "iz glave celog naroda" ["from the head of the entire nation"], while Mokranjac "peva iz glave i srca naroda" ["sings from the head and the heart of the nation"]. Therefore it would be "vredelo da narod i svet danas govore iz glave kompozitora Stevana

\footnotetext{
${ }^{8}$ Bora Dugić, Virtuelni razgovor sa Stevanom Stojanovićem Mokranjcem [Virtual Conversation with Stevan Stojanović Mokranjac], 2010, http://www.domkulture-negotin. $\mathrm{rs} / \mathrm{p}=2292$

9 Zoran Hristić, "Beseda" ["Keynote Address"], Baštinik, Godišnjak Istorijskog arhiva u Negotinu, 2006, 9, 132-134; Gordana Krajačić, Muzički zapisi [Writings on Music], Belgrade, authorial edition, 2011, 263.

${ }_{10}$ Niti tradicije u Mokranju [Threads of Tradition in Mokranje], 2010, http://www.domkulture-negotin.rs/?p=167.

11 Milovan Nikolić, op. cit., 146.
} 
Mokranjca, jezikom muzike!" ["worth it if the people and the world spoke from the head of the composer Stevan Mokranjac, in the language of music!"] ${ }^{12}$

The cult of Mokranjac in certain narratives is reinterpreted as the cult of Serbian nation, which is, like Mokranjac, presented as more unique and worthy than others. For example, Bradic in the foregoing speech concluded that it is "teška istina" ["hard truth"] that without Mokranjac "ovaj svet i Srbija bili sasvim drugačiji" ["this world and Serbia would be completely different"] ${ }^{13}$ while Ljubomir Trifunovski, the conductor of the Macedonian choir Stiv Naumov", called Mokranjac at the 2010 Singing Contest Forum the greatest composer "ne samo na Balkanu već i na svetu" ["not only in the Balkans, but also in the world"]. ${ }^{14}$ At the same forum, Milovan Pančić, the conductor of the choir Lola, asserted: "Blago nama što imamo Stevana Mokranjca. To nema niko... To je nešto veličanstveno, nešto što uzdiže svaki narod. Kroz svu njegovu muziku provlači se vera, slava, karakteristika, duh Srbije i ovih naših prostora... To samo ovaj narod ima i time treba da se diči i ponosi dok god je sveta i veka" ["We are blessed to have Stevan Mokranjac. Nobody else has such a man... This is something sublime, something that exalts every nation. All of his music is permeated with religion, glory, character, the spirit of Serbia and these parts of ours... This nation is the only one that has it, and this nation should be proud of it to all eternity"]. ${ }^{15}$

The most efficient means of glorifying the Serbian nation through Mokranjac is Serbian folklore, which is interpreted as the 'real', 'original', 'genuine' Serbian culture and key factor in strengthening Serbian identity. ${ }^{16}$ Returning to the 'sources' and 'roots' is at the same time returning to Mokranjac, as a composer whose works are based on Serbian folk music. ${ }^{17}$ For example, in his

12 Nebojša Bradić, Govor [The Speech], 2010, http://www.domkulture-negotin.rs/?p=2295.

13 Ibid.

${ }^{14}$ Cf. Maja Čolović Vasić, "Tribina Mokranjčevih dana" ["The Forum at Mokranjčevi dani"], Mokranjac, 2010, 12, 38.

${ }^{15}$ Cf. ibid., 36.

${ }^{16}$ Folklore is similarly interpreted in narratives on Dragačevski sabor trubača in Guča. Cf. Jelena Arnautović, "Čija je ovo truba? Medijski stereotipi o festivalu Guča kao simbolu srpskog kulturnog identiteta" ["Whose trumpet is this? Media stereotypes about the Guča festival as a symbol of Serbian cultural identity"], in: Milivoje Pavlović (ed.), Kulturna politika, umetničko stvaralaštvo i medijska praksa u funkciji održivog razvoja [Cultural Policy, Artistic Creativity, and Media Practice serving Sustainable Development], Belgrade, Univerzitet Megatrend, Fakultet za kulturu i medije, 2012, 287-300.

${ }^{17}$ Curiously enough, the fact that Mokranjac also drew his inspiration from the folklore of other countries (Croatia, Macedonia, Bosnia and Herzegovina, Turkey, Bulgaria...) is thereby usually forgotten (or deliberately disregarded?). A rare exception in this regard was the keynote address given by Branka Radović at the 2010 Singing Contest Forum. Cf. Maja Čolović Vasić, op. cit., 39. 
keynote address from 2003, composer Zoran Hristić pointed out that "u minulim godinama, ceo srpski narod prisustvovao demonstraciji muzičkog beščašća muzike vlasti, koja je doprinela da Rukoveti budu povremena iznenađenja osuđena na skrajnuto postojanje, jer je nametnut haremski zvuk Šumadiji koja će, umesto da igra kolo, vrteti kukovima i mahati rukama. Zaslepljena polumesecom, neće videti sopstveni krst" ["in past years, the whole Serbian nation has witnessed how disgraceful is the music of the establishment, which had reduced the Garlands to occasional surprises condemned to a marginal existence, because harem sound has been imposed on Šumadija, which will shake its hips and wave its arms instead of dancing circle dances. Blinded by the crescent moon, it will not see its own cross"]. ${ }^{18}$ Something similar was noted by Bora Dugić, when in an imaginary conversation he asked Mokranjac how he interpreted "estetsko posrnuće srpskog naroda" ["the aesthetic decline of Serbian people"]. Because "danas u Srbiji vlada neka druga muzika, stranci nas po pesmi mešaju sa Arapima i Turcima. Kada bi stranac došao u Srbiju sa zadatkom da po muzici prepozna gde se nalazi, mislio bi da je bilo gde samo ne $u$ Srbiji" ["today Serbia is dominated by some other music, and foreigners listening to our songs mistake us for Arabs and Turks. If foreigners came to Serbia and had to recognize by music where they were, they would think of anywhere but Serbia"]. To that Mokranjac allegedly replies: "Izgubili smo i pesmu i identitet. Ako posle pesme izgubimo i jezik, izgubili smo naciju... Izbrišite ono što nije dostojno srpskog junačkog, Veljkovog i Obilićevog, nađite tačku gde je narodni pevač i igrač stao. Pevajte srpsku pesmu na srpskom jeziku, to je jedino bogougodno. Skaredno je i rogobatno kad na svom jeziku pevate tuđe melodije. Voleti druge ne znači pustiti ih u svoj um dalje nego što bi vas pustili; ako vi zapevate jednu njihovu, neka oni zapevaju jednu našu. To jedino ima smisla" ["We have lost both our songs and our identity. If following our songs we lose our language too, we will have lost our nation... Erase what is not worthy of the heroics of the Serbs, of Veljko and Obilić, find the point where the folk singer and dancer stopped. Sing Serbian songs in the Serbian language, only this is God-pleasing. It is obscene and clumsy when you sing other people's songs in your own language. Loving others does not mean letting them into your mind deeper than they would let you into theirs; if you sing one of their songs, they should sing one of ours. Only that makes sense"]. ${ }^{19}$

Obviously, the proclaimed 'return' to Mokranjac and traditional folklore as the 'roots' and 'source of the Serbian nation's soul' is understood as a 'cure'

18 Zoran Hristić, op. cit., 132-134.

19 Bora Dugić, op. cit. These imaginary answers reflect not only Dugić's perception of Mokranjac, but also his own role as a musician and Mokranjac's potential 'heir'. Other keynote addresses can also be viewed from that angle, as multiple playing with identity. 
for the sorry condition of Serbian culture and potentially as a means for initiating a 'national revival'. In that way, these narratives transform Mokranjac, as the 'guardian' of Serbian folklore, into the incarnation of 'genuine' Serbian cultural and national identity, the quintessence of Serbian tradition, and ultimately a means of glorifying national power. Such interpretations are based on a mechanism which Slobodan Naumović, an anthropologist, calls the utilization or instrumentalization of tradition. It is a political strategy that detaches certain cultural values and fundamental symbols of a national community's identity from their original context and uses them for purposes not immanent to them, in line with its own interests. ${ }^{20}$ The narratives at Mokranjčevi dani instrumentalize a particular segment of Serbian musical tradition - Stevan Mokranjac and traditional folk music. Mokranjac "služi kao instrument za raznovrsne ideološke borbe koje zapravo i postoje u srpskom društvu" ["serves as an instrument in various ideological struggles which in fact do exist in Serbian society"], ${ }^{21}$ and so the myth of Mokranjac assumes the properties of a political myth. ${ }^{22}$

In the same way we can understand the tendency to establish continuity between Mokranjac and some other figures considered important for Serbian culture and history. In the narratives at Mokranjčevi dani, Mokranjac is most often compared to Hajduk Veljko Petrović, the hero of Negotinska Krajina. ${ }^{23}$ Keynote speakers have also called Mokranjac "the Vuk Karadžić of folk music", wanting to stress that his contribution to Serbian music is equal to that of Vuk Karadžić to the Serbian language. "Mi danas zborimo Vukovim, a pevamo Mokranjčevim srpskim jezikom" ["Today, we speak the Serbian language of Vuk and sing the

${ }^{20}$ Cf. Slobodan Naumović, Upotreba tradicije u političkom i javnom životu Srbije na kraju dvadesetog $i$ početkom dvadeset prvog veka [Utilization of Tradition in the Political and Public Life of Serbia in the Late Twentieth and Early Twenty-First Centuries], Belgrade, Institut za filozofiju i društvenu teoriju, IP “Filip Višnjić” a. d., 2009, 14, 19, 20.

21 Vesna Mikić, op. cit., 5.

22 Slobodan Naumović defined a political myth as "posebnu vrstu mitske priče u kojoj se nude odgovarajuća sećanja na izmišljenu ili stvarnu prošlost i slike poželjne budućnosti u cilju objašnjavanja i opravdavanja političke sadašnjosti, i izazivanja kolektivnih osećanja i akcija" ["special kind of mythic narrative which offers appropriate remembrance of the past, whether imaginary or real, as well as images of a desirable future, in order to explain and justify the political present and provoke collective emotions and actions"]. Slobodan Naumović, op. cit., 97.

${ }^{23}$ It is known that Mokranjac dedicated his Sixth Garland to Hajduk Veljko, and that this work is performed every year at the opening ceremony of Mokranjčevi dani as a sort of festival anthem. It is worth noting that Hajduk Veljko's monument in Negotin and Mokranjac's Sixth Garland are considered the main symbols of Negotin. Cf. Stojan Todorović, "Rukovet za junaka" ["Garland for a hero"], Politika, 12 September 2002. 
Serbian language of Mokranjac"]. ${ }^{24}$ Mokranjac is also compared to other great Serbs, such as Karađorđe, Saint Sava, Dositej Obradović, Njegoš, and Nikola Tesla, ${ }^{25}$ but also to some composers and performers of modern age, who are called the perpetuators of "mokranjčevske linije" ["Mokranjac's course"] ${ }^{26}$ or "Mokranjčevi sledbenici" ["Mokranjac's successors"]. ${ }^{27}$ Some narratives of this type have a latent tendency to depict Mokranjac as the 'original source' ( $U r$ quelle) of Serbian music, which, in one way or another, gave birth to everything 'valuable' in Serbian music of the $20^{\text {th }}$ and $21^{\text {st }}$ centuries. ${ }^{28}$

Creating a (fictional) continuity with a desirable historical past makes it easier to construct the notion of a common tradition within a certain community, and so we can speak of mechanisms of imagining a nation, or even inventing tradition. ${ }^{29}$ National identity in such narratives is treated as a homogenous,

${ }^{24}$ Milovan Nikolić, op. cit., 146; Miodrag Maticki, "Beseda" ["Keynote Address"], Baštinik, Godišnjak Istorijskog arhiva u Negotinu, 2006, 9, 141; Adam Puslojić, "Poruka i oporuka Stevana Stojanovića Mokranjca" ["The Message and the Testament of Stevan Stojanović Mokranjac"], Mokranjac, 2013, 15, 20.

${ }^{25}$ For instance, the fact that Mokranjac and Nikola Tesla, "dva velika uma, dva velika Srbina" ["two great minds, two great Serbs"], were born in the same year is not a mere coincidence for Bora Dugić, but a "Božiji razlog" ["God's reason"], because both of them "zauvek svojim delom zadužili pre svega čovečanstvo, a onda i srpski narod" ["with their work, they both forever indebted humankind, first of all, and then also the Serbian people"]. Bora Dugić, op. cit.

${ }^{26}$ Branka Radović, "Moj selektorski kredo" ["My creed as a Programming Director"], Mokranjac, 2008, 10, 36. They primarily include composers who write (choral) works inspired by folklore. For example, in an article on Mokranjčevi dani written in 2002, Gordana Krajačić saw Svetislav Božić and Miodrag Govedarica as "duhovne potomke i poslednike Mokranjca" ["spiritual descendants and successors of Mokranjac"]. Gordana Krajačić, "Mokranjčevi blistavi tragovi" ["In the Resplendent Wake of Mokranjac"], Blic, 16 September 2002.

27 The Cultural Centre in Negotin organizes an annual non-festival event Zvuci Mokranjčevih sledbenika [Sounds of Mokranjac's Successors], dedicated to young music professionals from Negotin.

28 “Umetničko-kulturno-ideološke 'borbe' vode se sada u odnosu na to ko je bliži Mokranjcu, ko ga više poštuje, ko na pravilan način ceni vrednosti koje je navodno on ustanovio, ili nam pak njegovo ime, kao simbol svih pomenutih ideoloških pretpostavki, služi kao njihov zastupnik, onaj koji pokriva, udahnjuje vrednost i opravdava različite aspekte života savremenog sveta muzike" ["Artistic-cultural-ideological 'struggles' are now led about who is closer to Mokranjac, who respects him more, who properly appreciates the values he allegedly established; on the other hand, his name, as a symbol of all the foregoing ideological assumptions, may also serve as their agent, the one who covers, valorizes, and justifies various aspects of contemporary music life"]. Vesna Mikić, op. cit., 7

29 According to Benedict Anderson, every nation builds its identity on choosing those elements from its cultural past (symbols, rituals, etc.) that may provide and confirm, at a given 
closed, monolithic, unvarying entity that has survived for centuries. In that respect, particularly typical is the keynote address by the philologist Miodrag Maticki from 2004, which portrayed Mokranjac as one of "divova, stožera kontinuiteta" ["the giants, the pivots of continuity"] who are "u samom središtu pamćenja našeg naroda" ["at the very heart of our people's remembrance"] and "na koje se oslanjaju protekli vekovi naše prošlosti" ["who are the anchors of the centuries of our past"]. "To je ono što vekovima živi u nama, što nas čini jedinstvenim i međusobno bliskim" ["This is what has lived on in us for centuries, what has made us unique and close to one another"]. And precisely this "snaga kontinuiteta srpske kulturne i političke prošlosti... pomogla je srpskome narodu da vekovima opstojava na ovim prostorima kao jedinstveni identitet" ["energy of continuity of Serbian cultural and political past... has helped the Serbian nation to survive for centuries in these parts as an indivisible identity"]. Because "postoji zajednička jezgra, opšta, delatna i bremenita, spremna da se razvija i umnožava, da bogati i uzdiže vaskoliki srpski narod. Do te jezgre se dolazi samo ako se prate kontinuiteti. Samo se tako može dopreti do same matice koja je srpski narod pronela kroz tri milenija" ["there is a common kernel, universal, active and fruitful, ready to develop and multiply, to enrich and elevate the entire Serbian people. This kernel can be reached only by tracing the continuities. Only thus may one reach the same current that has carried the Serbian people over three millennia". ${ }^{30}$

Such discourses on Mokranjac have also defined the meaning of the festival Mokranjčevi dani. In 2008, the festival was held under the motto "Povratak izvorima" ["Returning to the Sources"], where the word 'sources' meant folklore tradition and choral music by Mokranjac and other authors. ${ }^{31}$ At the Forum organized within Mokranjěevi dani in 2003, the composer Konstantin Babić singled out this festival as one of the few which cultivate "našu, više nego ugroženu nacionalnu kulturu" ["our national culture, which is more than endangered"], as opposed to e.g. the repertoire policy of the Belgrade Philharmonic, which "ide putem globalizacije" ["treads the path of globalization"]. ${ }^{32}$

time, the idea of continuity and belonging to a certain territory. The aim of this process of imagining a community is to represent a heterogeneous society as a homogeneous social community. Benedikt Anderson [Benedict Anderson], Nacija: zamišljena zajednica [Nation: Imagined Community], trans. Nata Čengić and Nataša Pavlović, Belgrade, Plato, 1998, 17-19. Invented tradition is Eric Hobsbawm's concept. Cf. Slobodan Naumović, op. cit., $13,27$.

${ }^{30}$ Miodrag Maticki, op. cit., 140-143.

31 Maja Čolović Vasić, "Mokranjčevi dani 2008”, Mokranjac, 2008, 10, 40-43.

${ }^{32}$ Cf. Stojan Todorović, "Na istoku Srbije"["In the East of Serbia"], Glas, 14 September 2003. 
Certain keynote addresses and speeches at Mokranjčevi dani had nothing to do with the festival, Mokranjac, or even music. They were dedicated to Eastern Orthodoxy. Discourses on the Orthodoxy have the same function as the discourse on folklore: they are a call to 'return to the roots' which should become a key tool in the 'national revival'. Thus in his keynote address delivered in 2002, the Academician Dejan Medaković, referring to the recent anniversary of Hilandar Monastery, asserted as our task to "pokušamo da uspostavimo duhovnu vezu sa trajnim vrednostima o kojima nas je učio Sveti Sava" ["try and establish a spiritual connection with the everlasting values that Saint Sava taught us about"] and "da se okrenemo svojem nacionalnom preporodu" ["to look towards our national revival"]. ${ }^{33}$ As the programming director, the composer Svetislav Božić at the closing ceremony of Mokranjčevi dani in 2003 gave a speech dedicated to the anniversary of the Church of the Holy Virgin in Negotin, ${ }^{34}$ and he concluded his address from 2001 with a cry: "Verujmo u Boga i u Srpstvo!" ["Let us trust in God and in Serbdom!" $]^{35}$ In the foregoing and similar narratives, Mokranjčevi dani are depicted as 'a festival of Serbian nation', not taking into account that members of other nations and ethnic groups also participate in it. ${ }^{36}$

When the festival narratives speak of 'the culture of the Serbian people', they are in fact referring to an idealized, mythic notion of a culture from a distant past, which should become a model for building the contemporary 'national

33 Dejan Medaković, "Beseda" ["Keynote Address"], Baštinik, Godišnjak Istorijskog arhiva u Negotinu, 2006, 9, 125-131.

${ }^{34}$ In archaic language, resembling religious sermons, the programming director said: "Mokranjčevi dani, ne samo oni, u noći Roždestva okončani, no već sledeći, od ovog trenutka začeti, rođeni, nemaju prava na duhovne, moralne, strukovne greške. Previda je bilo isuviše i više ih ne sme biti... Mokranjčevi dani i Negotin moraju biti svetlost Tavorska, a ne Carigrad podno Karpata, žiška umašćenog agarjanskog fenjera na Bosforu, niti od zala, kišom i samoćom otežala kapucinerska megalomanija carstvujušče Vijene. Iznad čekića i nakovnja, iznad svakog zla, iznad Istoka i Zapada" ["Mokranjčevi dani, not only them, concluded in the night of the Nativity, but already the next festival, conceived in this moment, born, have no right to make spiritual, moral, professional mistakes. There were too many oversights and there can be no more... Mokranjčevi dani and Negotin must be the light from Mount Tabor, and not an Istanbul under Carpathians, the wick of a smeared Muslim lantern at the Bosporus, nor Capuchin megalomania of Imperial Vienna, engorged with evils, rain and solitude. Above hammer and anvil, above all evil, above the East and the West"]. Svetislav Božić, "Govor" [“'Speech”], Baštinik, Godišnjak Istorijskog arhiva u Negotinu, 2006, 9, $136,137$.

${ }^{35}$ Svetislav Božić, "Beseda" ["Keynote Address"], Baštinik, Godišnjak Istorijskog arhiva u Negotinu, 2006, 9, 124.

${ }^{36}$ On the repertoire policy of Mokranjčevi dani in the $21^{\text {st }}$ century see Jelena Arnautović, "Interkulturni dijalozi na Mokranjčevim danima" ["Intercultural Dialogues at Mokranjčevi dani”], Mokranjac, 13, 2011, 56-67. 
culture'. Particularly mythologized is the $19^{\text {th }}$ century, presented as the time of 'pure', 'original', 'undepraved' culture of the Serbian nation, which is corroborated with the fact that Mokranjac himself lived in the same period. In collective remembrance, this period is marked by the struggle of the Serbian people for independence, which these narratives interpret as a lesson for the current state of the Serbian nation. At the same time, some other periods of Serbian history are erased from memory as undesirable or inappropriate. For instance, there is a marked tendency to make a definite break with the nineties and to 'start over', ${ }^{37}$ although, paradoxically, the narratives in the $21^{\text {st }}$ century are largely an extension of the narratives from the late $20^{\text {th }}$ century (most of all, by their mythologization of the Serbian nation through Mokranjac). On the other hand, the significance of Mokranjac and Mokranjčevi dani was practically nil in the SFR Yugoslavia. If there are any recollections of that stage in the festival history, they are mostly negative. Especially severe criticisms are aimed at banning the Orthodox music concerts in churches at the time. ${ }^{38}$ One such example is Zoran Hristić's keynote address from 2003: “Čitave generacije u titoističkim školama vaspitavane su masovnim pesmama, bez šanse da čuju makar jedan takt, genijalne, Mokranjčeve liturgije!" ["Entire generations in Titoist schools were raised on mass songs, without a chance to hear even a single measure of Mokranjac's brilliant Liturgy!'] ${ }^{39}$ Performing Mokranjac's Liturgy thus became the symbol of liberation of the Serbian people from 'oppressors'. ${ }^{40}$

37 For example, Mokranjčevi dani in 2001 were announced in the Politika ekspres daily as "prvi nakon rušenja komunizma u Srbiji" ["the first after the demise of communism in Serbia"]. V. C., "Nismo razumeli naš duhovni koridor" ["We did not understand our spiritual corridor"], Politika ekspres, 14 September 2001. Also, there are no written sources on Mokranjčevi dani from the nineties. Commemorative volumes by Dejan Despić and Konstantin Babić deal with the period only up to 1990, the journal Mokranjac was launched in 2000, and even the website of Mokranjčevi dani does not cover the last decade of the $20^{\text {th }}$ century.

${ }^{38}$ A rare exception was a concert by the conductor Darinka Matić Marović and the choir Collegium musicum, held at Mokranjčevi dani in 1978. In the Old Church in Negotin, they performed Mokranjac's Divine Liturgy of St. John Chrysostom. Cf. Dejan Despić, Mokranjčevi dani 1966-1990, Negotin, Mokranjčevi dani, 1990, 46. The nineties saw a proliferation of sacred music concerts, which can also be noted in the programmes of Mokranjčevi dani.

39 Zoran Hristić, op. cit., 132.

40 In his keynote address from 2001, Svetislav Božić reinterpreted Mokranjac's music as "simbol večne patnje srpskog naroda" ["a symbol of the eternal suffering of the Serbian people"] because "mnogi proterani velikani, istinski rodoljubi proglašeni narodnim neprijateljima patili su i ridali za Stevanovom i sa Stevanovom pesmom" ["many exiled great men, true patriots who were declared public enemies, suffered and wept for Stevan's songs 
The effort to shape the remembrance of certain events from the past selectively, apparent in narratives from Mokranjčevi dani, can be interpreted analogously to the sociologist Todor Kuljić's definition of the culture of remembrance and the culture of forgetting. "Pamćenje sklapa selektivne sadržaje prošlosti u smisaoni poredak, uspostavlja sklad u prihvatanju i tumačenju sveta, ali naravno ne samo čuvanjem određenih sadržaja, već i zaboravom drugih. ... Sećanje je zahvat u prošlo uvek iz nove sadašnjice" ["Remembrance assembles selected themes from the past into a coherent arrangement, establishes harmony in accepting and interpreting the world - naturally, not only by preserving certain themes, but also by forgetting others... Remembrance is reaching into the past, always from a new present"] ${ }^{41}$ It is therefore interesting to recollect that Stevan Mokranjac, represented in today's narratives as a symbol of Serbian identity, was a symbol of Yugoslavism until three decades ago. ${ }^{42}$ In both cases, the process of utilizing tradition was and is in operation, albeit in different ways. For, as Naumović says, tradition is not a passive segment of the system; instead, each new generation of 'active recipients' chooses and reinterprets the traditional themes. ${ }^{43}$ And that means that in different contexts, one and the same tradition can be interpreted in different ways. In the process, the power wielders in a certain society and at a certain time will campaign for 'their' interpretation of tradition as the only valid and correct one. The problem with, or, rather, the danger from, such biased and ideologically coloured interpretations of Stevan

and with Stevan's songs"], and Mokranjac himself "delio sudbinu svoje braće po Veri i duhu" ["shared the fate of his brothers in Faith and spirit"]. The speaker then related this symbolism to the ban on Orthodox music in socialist Yugoslavia: "Dugo je ćutala njegova pesma, dugo su crkve čekale srpski rod, krila se Liturgija Zlatoustog od nas" ["For too long had his song kept quiet, for too long had the churches waited for the Serbian people to return to them, for too long had the Liturgy of Chrysostom been hidden from us"]. Svetislav Božić, "Beseda" ["Keynote Address"], op. cit., 123.

${ }^{41}$ Todor Kuljić, Kultura sećanja: teorijska objašnjenja upotrebe prošlosti [Culture of Remembrance: Theoretical Explanations of Utilization of the Past], Belgrade, Čigoja, 2006, 8.

42 Until 1990, the speakers at Mokranjčevi dani came from various parts of ex-Yugoslavia and Mokranjac was considered a Yugoslav composer. An example of such an interpretation of Mokranjac is an address by the musicologist Stana Đurić-Klajn from 1981, where she highlighted that Mokranjac composed " $u$ duhu jugoslovenskom, inspirišući se i obuhvatajući u svojim blistavim rukovetima narodne napeve Srbije, Makedonije, Crne Gore, Bosne i Hrvatske, pa je u tome njegov opštejugoslovenski značaj" ["in the Yugoslav spirit, finding inspiration in and encompassing in his brilliant Garlands the folk melodies of Serbia, Macedonia, Montenegro, Bosnia and Croatia, which constitutes his all-Yugoslav significance"]. Cf. Dejan Despić, op. cit., 125.

43 Slobodan Naumović, op. cit., 13, 14, 27. 
Mokranjac is that they come from individuals who enjoy a measure of credibility with the public; another problem is that such interpretations have been publicly pronounced at the festival Mokranjčevi dani or recorded in the texts about it. Thus everyone who attends the festival or reads about it in the media will receive the message that Mokranjac and the festival in his honour should be understood in the described manner, whereas the composer and the event are both so much more than that.

Interpretations of Stevan Mokranjac are also built on visions of the future. The most striking examples are the narratives about the festival Mokranjčevi dani in which Negotin, Mokranjac's hometown, is compared to other European cities where great composers were born. The festival chronicler Gordana Krajačić was among the first to make such a comparison. As early as in 2001 she wrote: "Salcburg se ponosi Mocartom, Bon Betovenom, Varšava Šopenom, a Negotin - najvećim srpskim kompozitorom - Stevanom Mokranjcem" ["Salzburg is proud of Mozart, Bonn of Beethoven, Warsaw of Chopin, and Negotin of the greatest Serbian composer - Stevan Mokranjac"]. ${ }^{44}$ In 2003, the same author concluded that Mokranjčevi dani was at the European level because it offered "sjaj svetskih festivala" ["the glamour of world festivals"], and in 2010 she ascertained that Negotin "iz godine u godinu sve više teži da postane naš Salcburg" ["is increasingly turning into our own Salzburg, year after year"].45 Comparison between Negotin and Salzburg has been particularly noticeable in Branka Radović's narratives since she became the programming director of Mokranjčevi dani in 2007. In her text "Moj selektorski kredo" ["My creed as a Programming Director"] she explicitly stated: "Negotin treba da postane naš Salcburg i naš Bajrojt, svetilište srpske muzike i kulture" ["Negotin should become our Salzburg and our Bayreuth, the sanctuary of Serbian music and culture"]. ${ }^{46}$ Moreover, when a Protocol on Co-Financing of Mokranjčevi dani, as a cultural event of high priority, was signed in 2010 with the Ministry of Cul-

${ }^{44}$ Gordana Krajačić, "Nebesna liturgija” ["Heavenly liturgy”], Blic, 14 September 2001.

${ }^{45}$ Gordana Krajačić, "Vertikala balkanske duhovne muzike" ["Pillar of Balkan sacred music"], Blic, 11 September 2003; Gordana Krajačić, Muzički zapisi, op. cit., 38.

${ }_{46}$ Branka Radović, op. cit., 37. She reiterated the same view two years later: "Salcburg je malo mesto koje je zahvaljujući Mocartu danas jedan od svetskih festivalskih centara - takav mora postati i Negotin u kome je rođen Stevan Stojanović Mokranjac" ["Salzburg is a small town that today, thanks to Mozart, is a global festival centre - this must also happen to Negotin, where Stevan Stojanović Mokranjac was born”]. Cf. Milomirka Jovović, "Sa Mokranjcem u svet" ["With Mokranjac into the World"], Mokranjac, 12, 2010, 29. The organizers and chroniclers of the festival have likewise adopted the same comparisons. Cf. Maja Čolović Vasić, "Mokranjčevi dani 2009”, Mokranjac, 2009, 11, 36; Maja Čolović Vasić, “Tribina Mokranjčevih dana" ["Forum of Mokranjčevi dani”], Mokranjac, 2010, 12, 38. 
ture, this partnership was symbolically named "Sa Mokranjcem u svet" ["With Mokranjac into the World"]. In the opinion of Milomirka Jovović, the festival director at the time, this justified the organizers' and programming director's view that "sazrelo vreme u kome Negotin mora postati svetski, muzički, kulturni i turistički centar" ["the time was ripe for Negotin to become the world centre of music, culture, and tourism"]. Signing of the protocol was an important step towards making Mokranjac's works "pronose svetom" ["resonate around the world"] and turning them into "zajedničko kulturno nasleđe jugoistočne Evrope" ["collective cultural heritage of Southeast Europe"]. For his oeuvre was "čuvan i razvijan" ["preserved and cultivated"] "baš sa tim ciljem da nas prepozna i preporuči svetu" ["precisely to make us recognizable and present us to the world"].47

Therefore, in the narratives at the beginning of the $21^{\text {st }}$ century, Mokranjac and Mokranjčevi dani have become a Serbian brand and a kind of 'ticket to Europe'. This can also be exemplified by the keynote address of Ivan Tasovac, a long-standing director of the Belgrade Philharmonics, from 2008. Unlike most of his predecessors, who saw the preservation of Serbian folklore and national identity as that continuity between Mokranjac and the present time, Tasovac perceived this continuity in communication with other European countries. Namely, Mokranjac is important to him primarily as the man "koji je pre više od sto godina razrešio pitanje o sopstvenoj umetničkoj egzistenciji u evropskom kontekstu znanja, iskustava i vrednosti... koji nas je svojim talentom upisao na svetsku muzičku mapu, koji nam je zadao standarde i potvrdio da istorija ne poznaje kategoriju nerealizovanog talenta" ["who over a hundred years ago solved the issue of his own artistic existence in the European context of knowledge, experience, and values... whose talent put us on the world map of music, who set the standard for us and confirmed that history does not recognize the category of wasted talent". ${ }^{48}$ Here Mokranjac is again understood as a model, a worthy example from the past and a guide for the future of Serbian culture, but the aspect to which we should look up is different. With the speakers discussed so far, this aspect concerned looking toward Serbian cultural heritage which, in their interpretation, became 'immaculate source' and the paradigm of 'true values of Serbian culture', whereas here the emphasis is on Mokranjac's cosmopolitism, his skill to use his own talent in the best possible way and to

\footnotetext{
47 Milomirka Jovović, op. cit., 28, 29. The extent of the exorbitance and groundlessness of this statement can be seen from the fact that the protocol with the Ministry was signed for only two years. Upon the expiration of this agreement, the organizers of Mokranjčevi dani were again forced to 'cope' with unstable and insufficient financial resources.

${ }^{48}$ Ivan Tasovac, "Beseda" ["Keynote Address"], Mokranjac, 2008, 10, 38.
} 
present it beyond the boundaries of Serbia at the time. ${ }^{49}$ Also, this particular narrative shows signs of utilizing tradition, but to a different end. That is to say: a discourse on Mokranjac who is no longer a Yugoslav, nor 'a great Serb', but a cosmopolitan and a European, in an echo of the post-socialist transition ideology of the necessity of Serbia becoming a member of the European Union.

In conclusion of the analysis, what this paper ultimately shows is that discourses on Mokranjac, as one of the most significant composers in the history of Serbian music, reflect our attitude towards ourselves and the community to which we belong. Interpretations of Mokranjac have changed over the historical course of Mokranjčevi dani, in line with changes of dominant ideologies and differences in personal perceptions. Thus we came from a Mokranjac who deeply felt the fellowship of the Yugoslav people, to Mokranjac as an expression of the eternal suffering of the Serbian nation, to Mokranjac the cosmopolitan and successful manager. These various 'faces' of Stevan Mokranjac reflect the various ways in which musical tradition, as a powerful means of identification, may be utilized, invented, selectively remembered or in fact forgotten.

The common ground between all of these narratives, which are seemingly disparate, is that they all treat Mokranjac as a sort of 'place of collective memory' serving to determine a collective and personal identity. In some narratives in the $21^{\text {st }}$ century, this identity is based on denying the immediate past and re-

\footnotetext{
49 Approaching Mokranjac's biography from the perspective of an (orchestra) manager, Tasovac is particularly fascinated by the fact that Mokranjac, in spite of financial difficulties, acquired education abroad, that he pragmatically chose to devote himself to the genre of choral music aware that it was the certain way of getting it performed in Serbia, that he managed to tour foreign countries with Belgrade Choral Society, and established the first music school and the first string quartet. "Zbog svega toga mislim da je Mokranjac ne samo originalan savremeni umetnik renesansnog tipa koji je u malu sredinu doneo duh evropskih vrednosti već ga možemo smatrati i prvim uspešnim menadžerom u našoj muzičkoj kulturi koji nam je ostavio mogućnost da je, ukoliko imamo viziju i preuzmemo na sebe odgovornost, moguće sanjati i srpski san o uspehu, ma koliko nam polazna tačka delovala bezizlazno" ["Given all of that, I think that Mokranjac was not only an original contemporary artist of the renaissance type, who brought the spirit of the European values into a provincial setting, but that we may also consider him the first successful manager in our musical culture, who bequeathed to us with the possibility, should we have a vision and take responsibility upon ourselves, to dream a Serbian dream of success, however hopeless the starting point might seem"]. Therefore, in the speaker's opinion, Mokranjac's experience is important for us today, because we, just like him back then, are starting "iz neke vrste istorijskog minusa" ["from a sort of historical deficit"] and therefore should spend the precious time "na akciju čiji cilj je uključenje u magistralne tokove svetske kulturne istorije, kojoj, konačno, pripadamo" ["in taking action aimed at joining the main flows of global cultural history, to which, after all, we belong”]. Ibid., 39.
} 
turning to an idealized $19^{\text {th }}$ century, i.e. 'the sources' and 'the roots' of Serbian culture, which are understood as folklore and Orthodox Christianity. For others, Mokranjac is a brand that can help us make a better showing on the international stage, thus building an identity on 'the European civic values'. In both cases, the discourse around Mokranjac is used in an attempt to find a solution to the identity crisis and rift that have afflicted Serbian society for many years.

Translated by Goran Kapetanović 